\title{
Content Usage and the Most Frequently Read Articles of 2017
}

\author{
Phil Lupo, MLIS, Anne Victoria Neale, PhD, MPH, Marjorie A. Bowman, MD, MPA, \\ and Dean Seebusen, MD, MPH
}

2017 was the 30th year of print and 15th year of online publication of the Fournal of the American Board of Family Medicine ( $7 A B F M)$. Here we provide our annual report of articles published in 2017 that were of greatest interest to our readers. Table 1 shows the 3 most frequently read articles by issue in 2017. Once again, original research proves to be the most-read type of article.

In addition, we provide an update on the content usage statistics over the past 8 years. Figure 1 illustrates the number of total access events for $7 A B F M$ content from 2010 to 2017. The year 2017 was the busiest year for online usage activity in $7 A B F M$ 's history, with an average of 772,473 content usage requests a month, and a total of 9.26 million during the year. Content activity was up 25\% in 2017 compared with content usage requests during 2016 and, when compared with 2010 , we note a $274 \%$ increase. Full-text articles were the most accessed during 2017, with an average of 265,793 monthly requests, followed by abstracts, with 226,846 average monthly requests, and then PDF articles, with 155,010 average monthly requests.

As always, we welcome reader feedback about published articles. Comments about specific articles can be posted to the $7 A B F M$ Web site (www. jabfm.org) by selecting "Responses" to the right of the article text. Letters to the editor can also be submitted for peer review and publication using the author portal.

To see this article online, please go to: http://jabfm.org/content/ 31/3/312.full.

\section{References}

1. Parchman ML, Von Korff M, Baldwin LM, et al. Primary Care Clinic Re-Design for Prescription Opioid Management. J Am Board Fam Med 2017; 30:44-51.

Conflict of interest: The authors are editors of the $7 A B F M$.
2. Anderson KL, Strowd LC. Epidemiology. Diagnosis, and Treatment of Scabies in a Dermatology Office. J Am Board Fam Med 2017;30:78-84.

3. Alcalá HE, Chen J, Langellier BA, Roby DH, Ortega AN. Impact of the Affordable Care Act on Health Care Access and Utilization Among Latinos. J Am Board Fam Med 2017;30:52-62.

4. Woolsey S, Brown B, Ralls B, Friedrichs M, Stults B. Diagnosing Hypertension in Primary Care Clinics According to Current Guidelines. J Am Board Fam Med 2017;30:170-7.

5. Balasubramanian BA, Cohen DJ, Jetelina KK, et al. Outcomes of Integrated Behavioral Health with Primary Care. J Am Board Fam Med 2017;30:130-9.

6. Edwards BA, Powell JR, McGaffey A, et al. Fitwits ${ }^{\mathrm{TM}}$ Leads to Improved Parental Recognition of Childhood Obesity and Plans to Encourage Change. J Am Board Fam Med 2017;30:178-88.

7. Ebell MH, Marchello C, Callaha M. Clinical Diagnosis of Bordetella Pertussis Infection: A Systematic Review. J Am Board Fam Med 2017;30: 308-19.

8. Moore MA, Coffman M, Jetty A, Klink K, Petterson S, Bazemore A. Family Physicians Report Considerable Interest in, but Limited Use of. Telehealth Services. J Am Board Fam Med 2017; 30:320-30.

9. Djuric Z, Segar M, Orizondo C, et al. Delivery of Health Coaching by Medical Assistants in Primary Care. J Am Board Fam Med 2017;30:362-70.

10. Davis MA, Lin LA, Liu H, Sites BD. Prescription Opioid Use among Adults with Mental Health Disorders in the United States. J Am Board Fam Med 2017;30:407-17.

11. Eastment MC, McClintock AH, McKinney CM, Narita M, Molnar A. Factors That Influence Treatment Completion for Latent Tuberculosis Infection. J Am Board Fam Med 2017;30:520-7.

12. Byhoff E, Cohen AJ, Hamati MC, Tatko J, Davis MM, Tipirneni R. Screening for Social Determinants of Health in Michigan Health Centers. J Am Board Fam Med 2017;30:418-27.

13. Kozakowski SM, Pugno PA. The American Board of Fam Med: New Tools to Assist Program Directors and Graduates Achieve Success. J Am Board Fam Med 2017;30:567-9. 
Table 1. The Three Most Frequently Read Articles in the Journal of the American Board of Family Medicine, 2017, Volume 30, By Issue

Jan/Feb 2017

1. Parchman ML, Von Korff M, Baldwin LM, et al. Primary Care Clinic Re-Design for Prescription Opioid Management. Original Research: http://jabfm.org/content/30/1/44.full (1).

2. Anderson KL, Strowd LC. Epidemiology, Diagnosis, and Treatment of Scabies in a Dermatology Office. Original Research: http://jabfm.org/content/30/1/78.full (2).

3. Alcalá HE, Chen J, Langellier BA, Roby DH, Ortega AN. Impact of the Affordable Care Act on Health Care Access and Utilization Among Latinos. Original Research: http://jabfm.org/content/30/1/52.full (3).

Mar/Apr 2017

1. Woolsey S, Brown B, Ralls B, Friedrichs M, Stults B. Diagnosing Hypertension in Primary Care Clinics According to Current Guidelines. Original Research: http://jabfm.org/content/30/2/170.full (4).

2. Balasubramanian BA, Cohen DJ, Jetelina KK, et al. Outcomes of Integrated Behavioral Health with Primary Care. Original Research: http://jabfm.org/content/30/2/130.full (5).

3. Edwards BA, Powell JR, McGaffey A, et al. Fitwits ${ }^{\mathrm{TM}}$ Leads to Improved Parental Recognition of Childhood Obesity and Plans to Encourage Change. Original Research: http://jabfm.org/content/30/2/178.full (6).

May/June 2017

1. Ebell MH, Marchello C, Callaha M. Clinical Diagnosis of Bordetella Pertussis Infection: A Systematic Review. Original Research: http://jabfm.org/content/30/3/308.full (7).

2. Moore MA, Coffman M, Jetty A, Klink K, Petterson S, Bazemore A. Family Physicians Report Considerable Interest in, but Limited Use of, Telehealth Services. Original Research: http://jabfm.org/content/30/3/320.full (8)

3. Djuric Z, Segar M, Orizondo C, et al. Delivery of Health Coaching by Medical Assistants in Primary Care. Original Research: http://jabfm.org/content/30/3/362.full (9)

Jul/Aug 2017

1. Davis MA, Lin LA, Liu H, Sites BD. Prescription Opioid Use among Adults with Mental Health Disorders in the United States. Original Research: http://jabfm.org/content/30/4/407.full (10).

2. Eastment MC, McClintock AH, McKinney CM, Narita M, Molnar A. Factors That Influence Treatment Completion for Latent Tuberculosis Infection. Original Research: http://jabfm.org/content/30/4/520.full (11).

3. Byhoff E, Cohen AJ, Hamati MC, Tatko J, Davis MM, Tipirneni R. Screening for Social Determinants of Health in Michigan Health Centers. Original Research: http://jabfm.org/content/30/4/418.full (12).

Sep/Oct 2017

1. Kozakowski SM, Pugno PA. The American Board of Family Medicine: New Tools to Assist Program Directors and Graduates Achieve Success. Commentary: http://jabfm.org/content/30/5/567.full (13).

2. Summers Holtrop J, Hall TL, Rubinson C, Dickinson LM, Glasgow RE. What Makes for Successful Registry Implementation: A Qualitative Comparative Analysis. Original Research: http://jabfm.org/content/30/5/657.full (14).

3. Fiscella K. Improving the Health of Patients and Communities: Evolving Practice-based Research (PBR) and Collaborations. Commentary: http://jabfm.org/content/30/5/562.full (15).

\section{Nov/Dec 2017}

1. Schoenborn NL, Lee K, Pollack CE, et al. Older Adults' Preferences for When and How to Discuss Life Expectancy in Primary Care. Original Research: http://jabfm.org/content/30/6/813.full (16).

2. Belden JL, Koopman RJ, Patil SJ, Lowrance NJ, Petroski GF, Smith JB. Dynamic Electronic Health Record Note Prototype: Seeing More by Showing Less. Original Research: http://jabfm.org/content/30/6/691.full (17).

3. Lutz J, Gross R, Long D, Cox S. Predicting Risk for Opioid Misuse in Chronic Pain with a Single-Item Measure of Catastrophic Thinking. Brief Report: http://jabfm.org/content/30/6/828.full (18).

Source: Content usage statistics for the $7 A B F M$, January 2017 through February 2018, HighWire Press. Accessed March 6, 2018. Rankings are updated monthly and based on hits received by articles archived on the $7 A B F M$ Web site only.

14. Summers Holtrop J, Hall TL, Rubinson C, Dickinson LM, Glasgow RE. What Makes for Successful Registry Implementation: A Qualitative Comparative Analysis. J Am Board Fam Med 2017;30: 657-65.

15. Fiscella K. Improving the Health of Patients and Communities: Evolving Practice-based Research (PBR) and Collaborations. J Am Board Fam Med 2017;30:562-6.

16. Schoenborn NL, Lee K, Pollack CE, et al. Older Adults' Preferences for When and How to Discuss
Life Expectancy in Primary Care. J Am Board Fam Med 2017;30:813-5.

17. Belden JL, Koopman RJ, Patil SJ, Lowrance NJ, Petroski GF, Smith JB. Dynamic Electronic Health Record Note Prototype: Seeing More by Showing Less. J Am Board Fam Med 2017;30:691-700.

18. Lutz J, Gross R, Long D, Cox S. Predicting Risk for Opioid Misuse in Chronic Pain with a Single-Item Measure of Catastrophic Thinking. J Am Board Fam Med 2017;30:828-31. 
Figure 1. Total access events for Journal of the American Board of Family Medicine content from 2009 to 2017. An access event occurs each time a user opens a new screen on the Web site. Source: Content usage statistics for the JABFM, 2009 to 2017, HighWire Press. Accessed March 6, 2018.

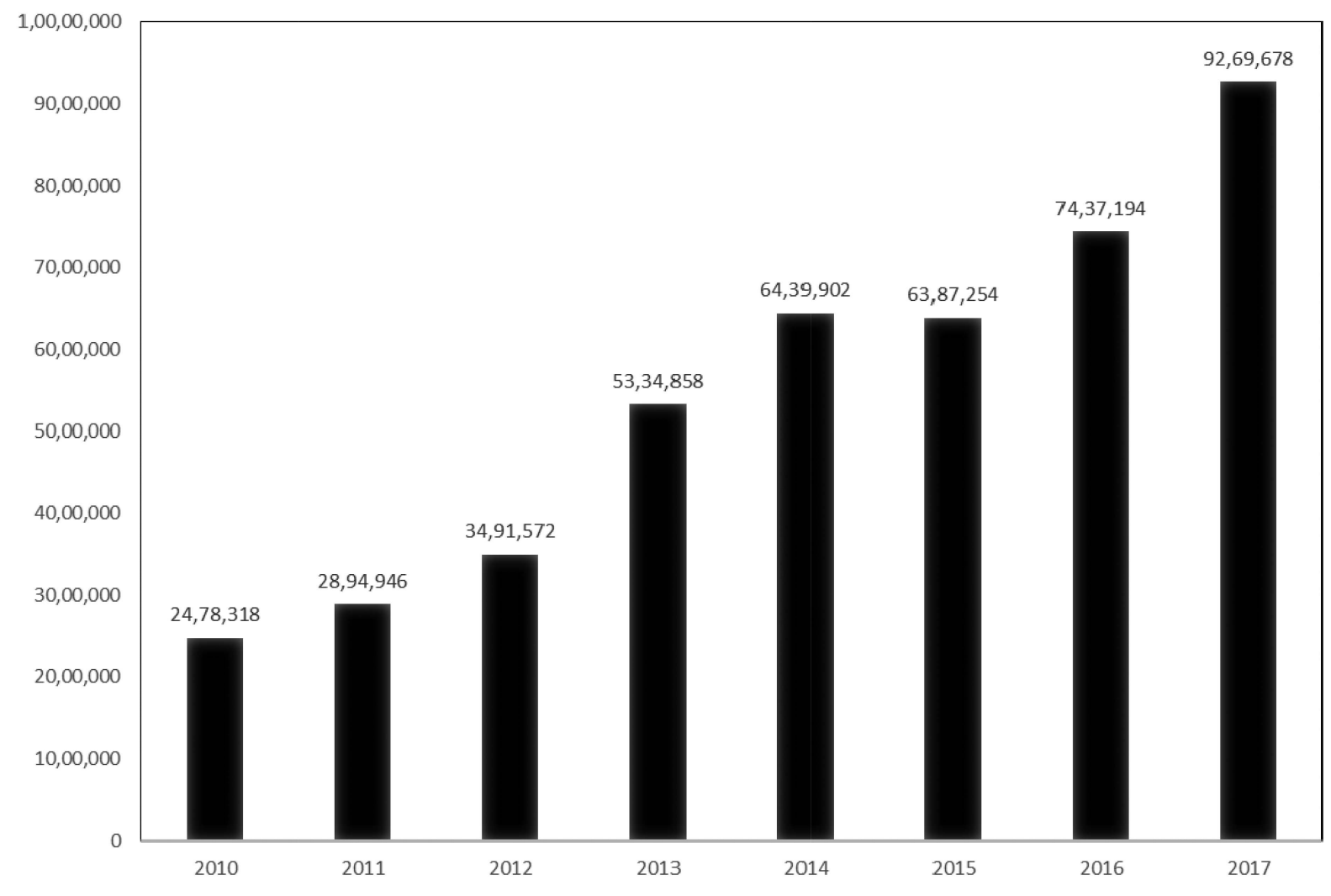

